\title{
ANALYSIS OF THE CORRELATION BETWEEN SOCIO-ECONOMIC DEVELOPMENT AND A NUMBER OF PLANNING DECISIONS ISSUED - EVIDENCE FROM PRZECŁAW MUNICIPALITY
}

\author{
Karol Król, Jarosław Markulis
}

\begin{abstract}
Summary
The purpose of the present work is to show the relationship between socio-economic development and the number of planning decisions issued in Przecław municipality in 2010-2016. It has been assumed that there is a greater interest in locating of construction investment projects in those villages and village districts, which have well-developed infrastructure and a greater number of service points for people and agriculture. It has been hypothesized that villages with the largest number of planning decisions issued are characterized by a high rate of socio-economic development. The analysis was carried out using Hellwig's method of taxonomic measure. It was demonstrated that in 2010-2016 period, the level of socio-economic development of the Przecław municipality was not correlated with the number of issued planning decisions (in the adopted research model).
\end{abstract}

\section{Keywords}

socio-economic development $\bullet$ planning decisions $\bullet$ spatial planning $\bullet$ management $\bullet$ taxonomic measure

\section{Introduction}

Shaping and development of space should take into account the welfare of local communities, considering their environmental and cultural conditions [Andrzejewska 2013]. The spatial planning process in Poland is regulated by the Act on spatial planning and land development [Ustawa 2003]. Among other things, it defines a catalogue of instruments that are available to local government units in their planning activities. The most important act of the local law in Poland, which defines the designation, the conditions for land management and development, as well as the distribution of public purpose investment projects and the manner of exercising the right of ownership, is a local spatial development plan (local plan, abbreviated as “MPZP”). In areas not covered by 
the local plan, its function is taken over by planning decisions (literally, "decisions on development conditions") [Skrenty 2010].

The planning decision document (abbreviated as "WZ" and commonly referred to as "wuzetka") is an administrative act (taking the form of an administrative decision), which formulates principles regarding the manner of construction and land development. The planning decision in its initial assumption was to perform an auxiliary function, and it was meant to support the planning and investment process. However, in fact it has become the basic instrument of local planning, applied by local government units. The overriding objective of a WZ planning decision is to determine whether the given investment objective will not violate spatial order. The planning decision is applied in the absence of a local plan in the area where the given investment project is planned - it allows for the change of land development designation, consisting in the construction of a building based on the provisions contained in the said decision [Jeżak and Wierzchowski 2014]. The body issuing the planning decision is the head of a municipality or the mayor of the city. In contrast to a building permit, anyone can obtain a WZ planning decision, also an entity that is not the owner of the given plot of land for which it is being drawn up. There is also the possibility of transferring the WZ planning decision, which became operational, to another person, if the applicant gives his consent thereto [Rokicka 2014]. Obtaining the planning decision is required when there is no local plan, and a change of land designation is planned, consisting in the construction of a building or other construction works, and when a change of use of the building or its part is being planned. The requirement to obtain a planning decision also applies to cases where a change of land designation is planned such as does not require a building permit. The change in use of the building or its part, the implementation of which does not require a building permit, is released from the obligation to obtain the planning decision. Also, the requirement to obtain the planning decision does not apply to temporary, one-time land change of use, lasting up to one year [Ustawa 2003]. When analysing the impact of the planning decision on broadly understood regional development, it is necessary to distinguish two types of decisions: (1) planning decision, or the "decision on development conditions" (WZ), issued for investment projects other than those for public purpose and (2) decision on location of public purpose investment projects (ULICP).

The planning decisions arouse much controversy. In the literature on the subject, their numerous imperfections are voiced, including: (1) the lack of transparency - WZ planning decisions are issued individually, per case, their execution is not accompanied by public consultations, and only parties to the proceedings are informed about the issuance of the WZ decision; (2) negative impact on spatial order of rural and urban areas - WZ planning decisions cause degradation of the landscape, disintegration of space, fragmentation of built environment, and spatial conflicts, which in consequence may cause difficulties with the planning and implementation of public purpose investment projects, (3) increasing land development costs, including costs of establishing water and sewage and road infrastructure, (4) lack of coherence of WZ planning deci- 
sions with the municipal local plan [Ziobrowski 2009, Jeżak and Wierzchowski 2014, Rokicka 2014, Król and Prus 2016].

The system pertaining to spatial planning and development should be as transparent as possible, enabling - on a local, regional and national scale alike - the maintenance of spatial order, and stimulating sustainable development. Nowak [2012] drew attention to the need of include planning decisions in the overall land management system, which would make it more consistent and would reduce the negative impact of the WZ planning decision on land development and spatial planning.

\section{Spatial planning versus socio-economic development}

Local government units are responsible for the implementation of public tasks, which in many cases means providing social commodities. Public tasks are implemented by the state or local government through their own organizational units, and by private sector entities as well as non-profit entities, in order to ensure an appropriate level of socio-economic development [Król 2016].

In developed countries, socio-economic development is associated with sustainable development, respecting the principles of environmental protection and the tenets of spatial order [Hełdak and Raszka 2013]. Socio-economic development is defined as the process of integrating political, economic and social activities, maintaining the natural balance and sustainability of natural processes, in order to guarantee the possibility of satisfying the basic needs of the community - both the contemporary and the future generations [Ziemiańczyk 2010, Chmielewski and Głogowska 2015, Król and Prus 2017]. Socio-economic development is associated with positive changes that lead to the improvement of the broadly defined quality of life. All the while, it is also important to preserve the idea of sustainable development, so that socio-economic growth does not adversely affect the natural environment.

Socio-economic development is defined as a process of positive quantitative and qualitative changes in the social and economic sphere as well as the sphere of production and the social sphere, with the aid of location factors, socio-economic factors along with technical and organizational factors [Ziemiańczyk 2010]. From an economic point of view, socio-economic development is associated with the growing number of investment projects, with an increase in production, employment figures, and the standard of living of the residents, together with an increase in the level of social and public safety. The main factors affecting socio-economic development include the activities of local government units of an administrative nature, aimed at levelling the disparities existing between regions, increasing the potential of technical infrastructure, selection of areas for the implementation of investment tasks, or planning activities. Local spatial development plans and planning decisions facilitate the protection and shaping (investment) of space in a manner consistent with the idea of sustainable growth, enabling social and economic development of the municipality [Hełdak and Raszka 2013].

The analyses of socio-economic development are most often performed in a spatial reference, with the use of a classification procedure that enables a multidimensional, 
spatial analysis of phenomena. Taxonomic methods make it possible to group specific objects according to accepted criteria and based on selected attributes into smaller, homogenous sets. Studies on the degree of socio-economic development at the local level are often based on a large number of variables describing, among others, availability of services, level of infrastructure provision, socio-economic activity, natural conditions, sources of budget revenues, and housing conditions. The selection of variables should be supported by the analysis of subject literature, and also it should take into account the spatial, temporal, as well as substantive scope and purpose of the analysis [Prus and Król 2017]. Moreover, the results of such analyses can be presented using various data visualization techniques and tools, in particular in the web browser window [Bedla and Król 2015, Król 2015, Król and Szomorova 2015, Król 2018, Król and Prus 2018].

\section{Material and methods}

The aim of the present work is to show the relationship between socio-economic development and the number of planning decisions issued in the Przecław municipality in the 2010-2016 period. The analysis covered decisions issued between 2010 and 2016. This time scope was adopted due to the recovery of municipal rights by the municipality of Przecław, which took place on January 1, 2010. The number of issued planning decisions was obtained from the Municipal Office in Przecław. A hypothesis was proposed that villages with the largest number of issued planning decisions are those that enjoy the highest degree of socio-economic development.

\subsection{Characteristics of the studied object and selection of diagnostic variables}

Przecław is a partly urban, partly rural municipality located in the western part of the Podkarpacie region (Podkarpackie Voivodeship), in the Mielec district (poviat) (Fig. 1). The seat of the municipal authorities is based in the town of Przecław. Przecław municipality is one of the largest municipalities in the region. The population is slowly but steadily growing. There are 11833 inhabitants living within the borders of the municipality (according to BDL for 2016). The area of the municipality is $134 \mathrm{~km}^{2}$. Przecław borders municipality of Radomyśl Wielki in the west; rural and urban municipality of Mielec in the north; the municipality of Niwiska in the east; and Dębica, Żyraków and Ostrów municipalities in the south. The municipality consists of 11 villages: Biały Bór, Błonie, Dobrynin, Kiełków, Łączki Brzeskie, Podole, Przecław, Rzemień, Tuszyma, Wylów and Zaborcze [Strategy of the Przecław Municipality 2016].

In 2016, the majority of residents were living in the village of Tuszyma, whereas the smallest population was recorded in the village of Zaborcze (Table 1). The town of Przecław, as the seat of the municipality, had a population of 1712 inhabitants. Przecław is one of the smallest cities in Poland in terms of population size. 


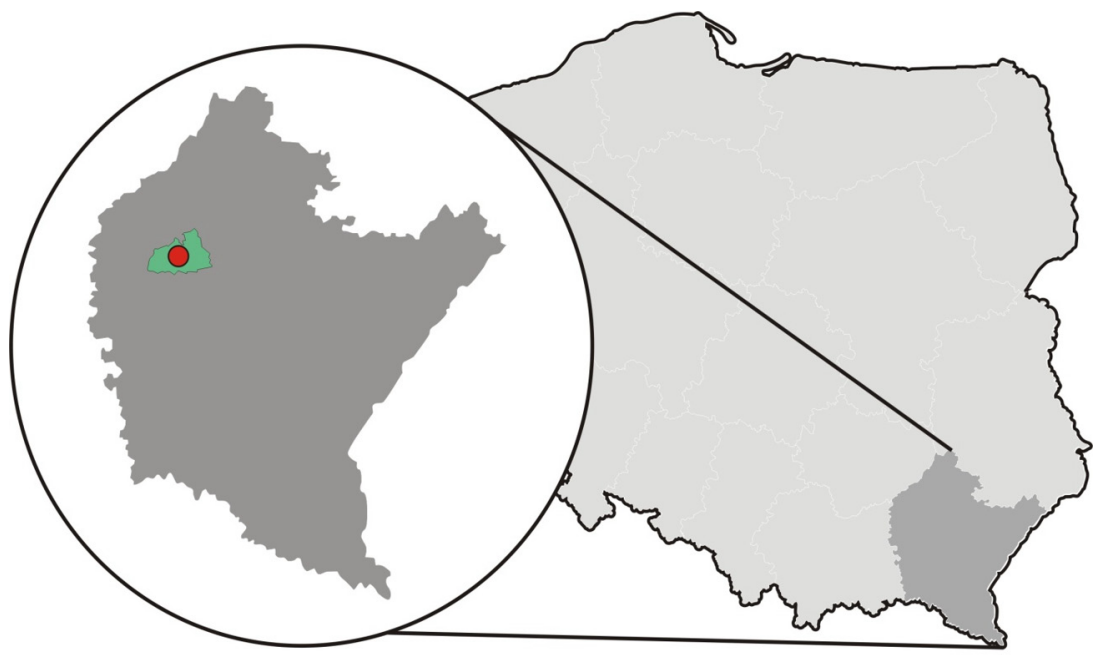

Podkarpackie voivodeship

Przectaw

Source: Authors' study

Fig. 1. Location of Przecław municipality in the Podkarpacie region (Podkarpackie voivodeship)

Table 1. Population size and area of particular villages [sołectwo] of Przecław municipality

\begin{tabular}{|c|c|c|}
\hline Sołectwo/village & $\begin{array}{c}\text { Population } \\
\text { [number of inhabitants] }\end{array}$ & Area $\left[\mathrm{km}^{2}\right]$ \\
\hline Biały Bór & 925 & 18.1 \\
\hline Błonie & 799 & 5.4 \\
\hline Dobrynin & 980 & 13.7 \\
\hline Kiełków & 830 & 8.5 \\
\hline Łączki Brzeskie & 1089 & 15.4 \\
\hline Podole & 1045 & 8.5 \\
\hline Przecław & 1712 & 16.3 \\
\hline Rzemień & 1357 & 25.4 \\
\hline Tuszyma & 2510 & 12.6 \\
\hline Wylów & 243 & 4.2 \\
\hline Zaborcze & 222 & 6.4 \\
\hline
\end{tabular}

Source: Authors's study based on Strategia Gminy Przecław [Strategy of the Przecław Municipality 2016] 
A significant area of the Przecław municipality is occupied by forests, which cover an area of 5664 ha and constitute $42 \%$ of the total surface (Table 2). The vast majority (84\%) are state forests administered by the Tuszyma Forest District. Przecław municipality is agricultural in nature. Agricultural land covers 6901 ha, which constitutes 51\% of the total area of the municipality. The most favourable soil conditions occur in the Lower Vistula Valley, with the predominance of soils that developed from silty clays and luvisols. Most forest areas belong to the Sandomierz Forest District (in Kotlina Sandomierska, i.e. Sandomierz Basin). These areas are valuable from both economic and recreational point of view [Strategy of the Przecław Municipality 2016].

Table 2. Forms of land use within Przecław municipality*

\begin{tabular}{|c|c|c|c|c|c|c|}
\hline \multirow{2}{*}{ Area } & \multicolumn{3}{|c|}{ Agricultural land } & \multirow{2}{*}{ Forests } & Other & Total \\
\cline { 2 - 4 } & Arable land & $\begin{array}{c}\text { Pastures and } \\
\text { meadows }\end{array}$ & Total & & \\
\hline $\begin{array}{c}\text { Przecław } \\
\text { municipality }\end{array}$ & 4809 & 2058 & 6901 & 5664 & 864 & 13429 \\
\hline
\end{tabular}

* in hectares [ha]

Source: Authors' study based on Strategia Gminy Przecław [Strategy for the Przecław Municipality 2016]

In the period in which the study was conducted, there were local plans adopted only for the following towns and villages: Przecław, Rzemień, Tuszyma and Zaborcze. The majority of investment areas were recorded in local plans prepared for the village of Rzemień (Table 3).

Table 3. Size of available investment areas in Przecław Municipality

\begin{tabular}{|c|c|c|c|c|}
\hline \multirow{2}{*}{ Designation in the local plan } & \multicolumn{4}{|c|}{ Sołectwa/villages } \\
\cline { 2 - 5 } & Przecław & Rzemień & Tuszyma & Zaborcze \\
\hline Size of areas designated for investment [ha] & 13.00 & 24.48 & 6.31 & 15.55 \\
\hline
\end{tabular}

Source: Authors' study based on local plans of Przecław municipality [Strategy for the Przecław Municipality 2016]

The main form of ownership of buildings in the Przecław municipality is private property. The existing multi-family buildings also belong to private owners. Since 1990, no multi-family building has been commissioned. All the building permits issued at that time concerned single-family buildings belonging to natural persons. Over the last 25 years, no building permit for a multi-family building has been issued. The technical infrastructure of the municipality is based on the water supply and 
sewage system. All villages of Przecław municipality are supplied with water from the intake in Biały Bór. The water is treated in a water treatment plant in Tuszyma. Currently, all villages have access to the water supply network. In addition, the villages of Przecław, Błonie, Rzemień and Kiełków are fully equipped with sewage systems. A mechanical and biological sewage treatment plant is located within the bounds of the municipality.

The most densely populated villages are Tuszyma, Błonie and Podole. The lowest population density has been recorded in the villages of Zaborcze and Biały Bór. Population in the Przecław municipality increased in 2015 from 85 to 87 people per $1 \mathrm{~km}^{2}$. Among the population of the Przecław municipality, people of working age are the dominant group, and the number of people of pre-working age is twice as large as the group in post-working age. There are no industrial plants within the borders of the municipality. On the other hand, there is a dynamically developing sector of small and medium-sized enterprises, most often family-owned, belonging to the production, trade and service industries. According to CEIDG (Central Register and Information on Economic Activity) and the online National Court Register, in 2015 in Przecław municipality there were 341 business entities in operation. The dominant type of entrepreneurship was self-employment ("economic activity conducted by natural persons"), which constituted $85 \%$ of all enterprises. The largest number of enterprises specialized in wholesale and retail trade as well as vehicle repairs. In addition, there is a steady increase in registered business entities within the municipality, which may indicate the dynamics of socio-economic development. As of December 31, 2015, approximately PLN 123.5 thousand unemployed persons were registered in the Podkarpacie region, including around 63.5 thousand women (who constituted $51.5 \%$ of the total number of unemployed persons). At the end of December 2015, about 7 thousand persons were registered as unemployed in the district Employment Office, including 3.7 thousand women (51.9\% of the total number of the unemployed) [Strategy of the Przeclaw Municipality 2016].

\subsection{Statistical analyses}

In order to verify the adopted hypothesis, a study was carried out to examine the level of socio-economic development of individual villages using Hellwig's method [Kopiński and Porębski 2014]. Diagnostic variables were selected based on the analysis of the subject literature [Prus and Król 2017, Prus et al. 2017, Prus and Szylar 2018] and classified into three categories: social, economic, and environmental (Table 4). The values of the variables were obtained from the Local Data Bank. Then standardization of variables was performed, and a pattern was adopted, in which the variables assumed the most favourable values. At the last stage, the so-called distances of individual objects from the standard were calculated. This made it possible to calculate a synthetic development index for each of the villages, and to order them according to the ranking. The results thus obtained were compared with the number of planning decisions that had been issued. 
Table 4. Diagnostic variables used in the study

\begin{tabular}{|c|c|}
\hline No. & Diagnostic variables \\
\hline $\mathrm{X}_{1}$ & number of inhabitants per $1 \mathrm{~km}^{2}$ \\
\hline $\mathrm{X}_{2}$ & non-working age population per 100 persons in working age \\
\hline $\mathrm{X}_{3}$ & number of persons working per 1000 inhabitants \\
\hline $\mathrm{X}_{4}$ & registered unemployment rate \\
\hline $\mathrm{X}_{5}$ & commissioned housing per 1000 inhabitants \\
\hline $\mathrm{X}_{6}$ & total expenditures from the village fund per 1 inhabitant in PLN \\
\hline $\mathrm{X}_{7}$ & self-employed persons per 100 persons in working age \\
\hline $\mathrm{X}_{8}$ & companies registered in the REGON register per 1000 inhabitants \\
\hline $\mathrm{X}_{9}$ & risk of poverty rate \\
\hline $\mathrm{X}_{10}$ & forest cover [\%] \\
\hline $\mathrm{X}_{11}$ & segregated waste collected during one year, in tons \\
\hline $\mathrm{X}_{12}$ & size of protected areas [ha] \\
\hline $\mathrm{X}_{13}$ & water consumption during one year, per 1 inhabitant $\left[\mathrm{m}^{3}\right]$ \\
\hline
\end{tabular}

Source: Authors' study

The basis for the taxonomic measure analysis is the normalization of diagnostic variables. Standardization is an activity aimed at adopting diagnostic variables to the role of partial criteria in the process of assessing a complex phenomenon. Usually the diagnostic features are expressed in different units of measure, and they correspond to different numerical ranges. Therefore, the diagnostic variables were standardized according to the formula (1) below.

where:

$$
z_{i j}=\frac{x_{i j}-\bar{x}_{j}}{s_{j}}
$$

$z_{i j}$ - standardized value of $x_{i j}$,

$x_{i j}$ - standardized value of $j$ - of this variable for $i$-th object.

The normalization of variables made it possible to calculate the synthetic measure of socio-economic development for particular villages within the Przecław municipality $\left(d_{i}\right)$. The synthetic measure was calculated by determining the distance of individual features from the abstract standard, in accordance with formula (2).

where:

$$
d_{i}=1-\frac{D_{i 0}}{D_{0}}(i=1,2,3, \ldots, n)
$$

$d_{i}$ - synthetic index of development,

$D_{i 0}$ - the Euclidean distance of the object from the standard,

$D_{0}$ - critical distance of the object from the standard. 
The Euclidian distance of the object from the standard was determined by the formula (3), and the critical distance of the object from the standard was calculated according to the formula (4), with the standard deviation of the taxonomic distances determined using the formula (5).

$$
D_{i 0}=\sqrt{\sum_{j=1}^{m}\left(z_{i j}-z_{0 j}\right)^{2}}
$$

(distance of the $i$-th object from the standard object)

$$
D_{0}=\bar{D}_{0}+2 S_{0}
$$

where:

$\bar{D}_{0}$ - arithmetic mean of taxonomic distances,

$S_{0}-$ standard deviation of taxonomic distances.

$$
S_{0}=\sqrt{\sum_{i=1}^{n}\left(D_{i 0}-\bar{D}_{0}\right)^{2}}
$$

The synthetic index of development (development rate) of $d_{i}$ falls within the range from 0 to 1 . The higher the value of the index, the greater the degree of socio-economic development is (in the adopted research model). A multidimensional spatial analysis of phenomena was performed by means of a classification procedure, which consisted in separating multi-feature homogeneous subgroup objects in a set [Hellwig 1981]. Particular villages were classified in terms of the level of their socio-economic development based on the arithmetic mean value and the standard deviation. This made it possible to determine their respective classes, or qualitative ranges:

- Class A - villages displaying the highest level of socio-economic development (within the adopted set). The value of the synthetic $d_{i}$ index is higher than the arithmetic mean of the variable, which has been increased by the standard deviation of the given feature (villages were qualified as class $\mathrm{A}$, if the value of their $d_{i}$ was greater than the value of $\left(\bar{d}_{i}+S_{d}\right)$.

- Class B - villages displaying the average level of socio-economic development. The value of their synthetic index falls within the range of $\left(\bar{d}_{i}-S_{d}, \bar{d}_{i}+S_{d}\right)$.

- Class C - villages displaying the lowest level of socio-economic development. The value of their synthetic index is lower than the value of $\left(\bar{d}_{i}-S_{d}\right)$, where:

$\bar{d}_{i}-$ the arithmetic mean of the synthetic index $d_{i}$,

$S_{d}-$ standard deviation of the synthetic index $d_{i}$.

In the last stage of the study, the $r$-Pearson linear correlation coefficient was calculated in order to determine correlations between the variables. 


\section{Results}

In 2018 , only $1.93 \%$ of the Przecław municipality was covered by local plans. In the analysed period, about 100 planning decisions were issued each year. Most often they concerned the location of single-family residential buildings. The majority of planning decisions was issued in 2010 and 2011 (Fig. 2). The lowest number of planning decisions was issued in 2013, and it was about 30\% less than in 2010 and 2011.

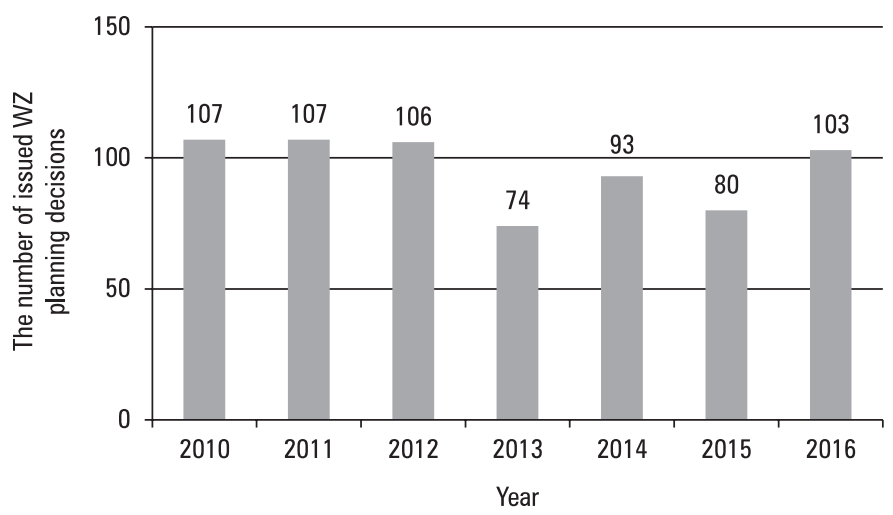

Source: Authors' study

Fig. 2. Number of planning decisions issued in Przecław during the 2010-2016 period

In 2015, the rate of dynamics of issuing planning decisions reached the highest value in the village of Łączki Brzeskie, and amounted to 320 percentage points. In that year, the largest number of planning decisions for investment projects planned in this particular village was also granted. In turn, the lowest rate of dynamics was recorded in 2012 in the village of Wylów, with a value equal to zero. For investment projects located in this village, only 12 planning decisions were issued throughout the analysed period, which was the lowest number of all the analysed villages. The number of decisions issued for this village was between 0 and 3 per year.

Significant discrepancies between individual villages in the number of planning decisions issued were observed in 2015 (Fig. 3). The most rapid growth in the rate of dynamics of the planning decisions granted was observed in 2014 and 2015.

The largest increase in the number of the planning decisions issued was recorded in the village of Tuszyma, where 11 decisions were issued in 2013, and as many as 25 in 2014. A characteristic situation in the case of the village of Rzemien was noted, in which after 2011 there was a large decrease in the number of planning decisions granted. This trend continued over the next years until 2016, when the investment revival took place. 


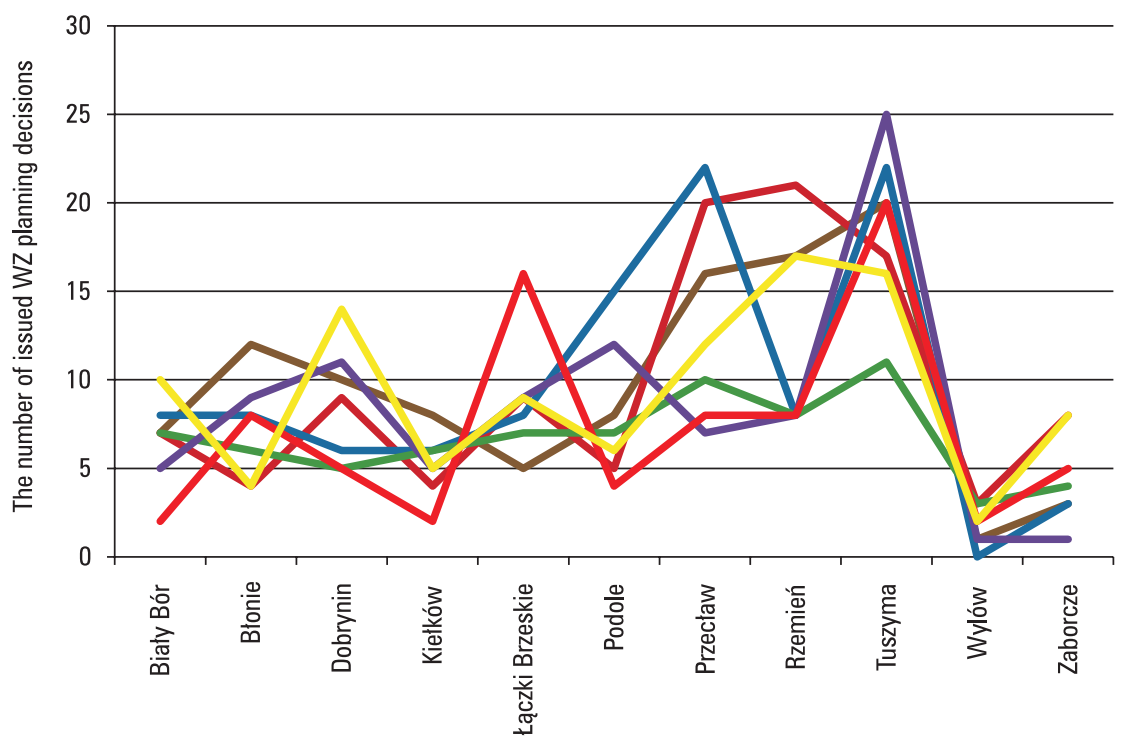

\footnotetext{
The number of planning decisions issued in 2010 The number of planning decisions issued in 2011

The number of planning decisions issued in 2012 The number of planning decisions issued in 2013

The number of planning decisions issued in 2014 The number of planning decisions issued in 2015

The number of planning decisions issued in 2016
}

Fig. 3. Number of planning decisions issued in Przecław during the 2010-2016 period, subdivided into particular villages

The village in which the most decisions on building conditions were issued in the analysed period was Tuszyma (131 planning decisions granted). The fewest planning decisions were issued for investment projects located in the village of Wylów (12 decisions granted). This much of an interest in investing in the village of Tuszyma may result from its location, directly on the provincial road No. 985, which connects to the A4 motorway. The village also plays a higher-level function within the municipality. Within its area, service points for citizens and for agricultural operations are concentrated. In addition, it was observed that in villages located in the central part of the municipality, there were more applications for planning decisions than in the remaining villages. The lowest number of planning decisions was issued in villages located on the outskirts of the municipality, which have a smaller number of inhabitants and a relatively inferior transportation connection. These are villages located in the eastern and western parts of the Przecław municipality. Furthermore, there is a smaller concentration of service points in these villages. Zaborcze and Wylów occupied respectively the second and third place in the ranking of socio-economic development. At the same 
time, the fewest planning decisions were granted in these villages. However, it should be noted here that Zaborcze had 56.1 ha covered with a local spatial development plan, which could have influenced the much lower number of the issued planning decisions. Whereas the villages of Podole and Dobrynin, the two with the lowest ranking, had respectively 57 and 60 planning decisions issued.

The largest number of planning decisions concerned single-family housing. Service development was concentrated in the village districts of Przecław and Tuszym. On the other hand, the agricultural areas covering the village districts of Łączki Brzeskie, Biały Bór, Zaborcze and Błonie stood out in respect to the location of farmsteads.

The analyses we have carried out made it possible to classify three village districts as class $\mathrm{A}$. They were distinguished by the highest rate of socio-economic development. Class B comprised the largest number of village districts, while in class $C$ included only 2 village districts (Table 5).

Table 5. Ranking of village districts of Przecław municipality, subdivided into classes of socioeconomic development compared to the number of planning decisions issued

\begin{tabular}{|c|c|c|c|c|}
\hline Rank & Village & $\begin{array}{c}\text { Value of } \\
\text { development } \\
\text { measure } d_{i}\end{array}$ & $\begin{array}{c}\text { Socio-economic } \\
\text { development } \\
\text { class }\end{array}$ & $\begin{array}{c}\text { Number of } \\
\text { planning } \\
\text { decisions issued } \\
\text { in 2010-2016 }\end{array}$ \\
\hline 1 & Tuszyma & 0.5722 & A & 131 \\
\hline 2 & Zaborcze & 0.5682 & A & 32 \\
\hline 3 & Wylów & 0.5642 & A & 12 \\
\hline 4 & Przecław & 0.4902 & B & 95 \\
\hline 5 & Rzemień & 0.4328 & B & 87 \\
\hline 6 & Błonie & 0.3996 & B & 51 \\
\hline 7 & Lączki Brzeskie & 0.3830 & B & 63 \\
\hline 8 & Kiełków & 0.3233 & B & 36 \\
\hline 9 & Biały Bór & 0.2847 & B & 46 \\
\hline 10 & Podole & 0.2279 & C & 57 \\
\hline 11 & Dobrynin & 0.2274 & C & 60 \\
\hline
\end{tabular}

Source: Authors' study

The highest value of the synthetic development index was obtained by the village of Tuszyma, characterized by the largest number of inhabitants. The lowest value of the index was obtained by Dobrynin and Podole. The villages, which have obtained the lowest value of the synthetic development index, are located away from the main communication routes, as compared to Tuszyma, which has the provincial road and the railway line running through it (Fig. 4). It should be noted, however, that the villages of Zaborcze and 
Wylów, which received high marks in the evaluation of socio-economic development, are also located at a considerable distance from the main communication routes.

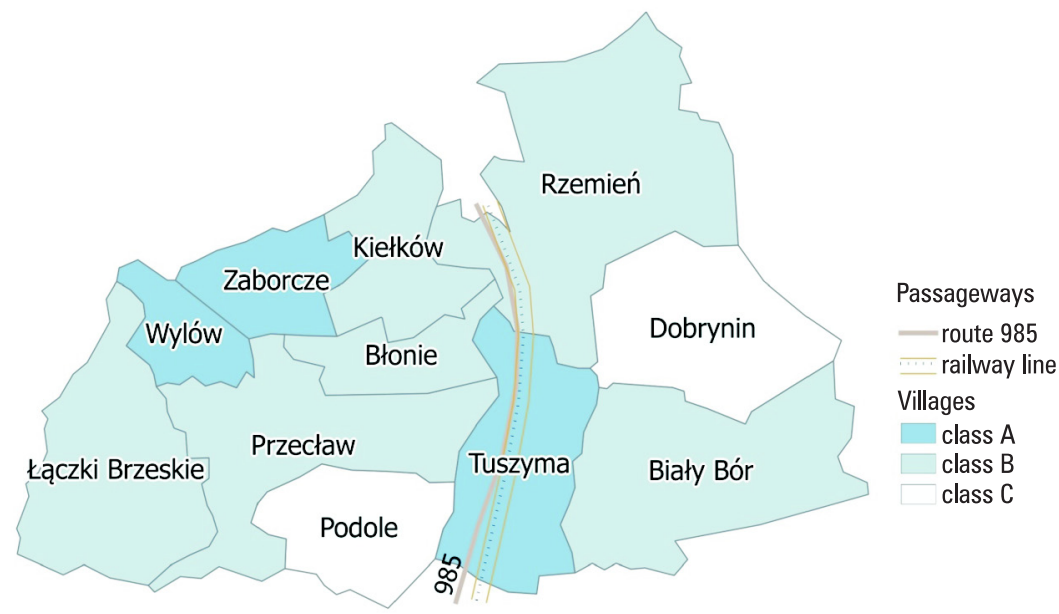

Source: Authors' study

Fig. 4. Classification of villages in the Przecław municipality into socio-economic development classes

The strength of correlation between the number of planning decisions and the level of socio-economic development was examined based on the analysis of the $r$-Pearson linear correlation coefficient. The coefficient of correlation between the synthetic ratio $\mathrm{d}_{\mathrm{i}}$ and the number of issued planning decisions was $r=0.173$. This means no linear correlation between socio-economic development and the number of planning decisions issued (in the adopted research model).

\section{Conclusions}

Socio-economic development can be stimulated through spatial planning. In a situation where there is no local zoning plan in existence, it is administrative decisions that decide the conditions of construction and land development - therefore, planning decisions. The latter should constitute an integral part of the spatial planning system, and serve as a tool for implementing the spatial development policy of the municipality, in accordance with the philosophy of sustainable development.

In Przecław municipality, there was no linear correlation between the number of issued planning decisions and socio-economic development of particular villages (in the adopted research model). At the same time, in such places as for instance Tuszyma, which obtained the highest synthetic index of socio-economic development, the largest 
number of issued planning decisions was recorded. In future research, it is advisable to revise and extend the number of diagnostic variables. Also, the impact of coverage by local plans on the number of issued planning decisions should be included in the future analysis.

\section{References}

Andrzejewska A.K. 2013. Planowanie przestrzenne - teoria a praktyka. Przestrzeń i Forma, 20, 205-220.

Bedla D., Król K. 2015. An interactive map of mountain river hydromorphological diversity case study. Geomat., Landmanag. Landsc. (GLL), 4, 17-27.

Chmielewski W., Głogowska M. 2015. Implementation of the Natura 2000 Network in Poland - an Opportunity or a Threat to Sustainable Development of Rural Areas? Study on Local Stakeholders' Perception. Eastern European Countryside, 21 (1), 153-169.

Hellwig Z. 1981. Wielowymiarowa analiza porównawcza i jej zastosowanie w badaniach wielocechowych obiektów gospodarczych. Wydawnictwo PWE, Warszawa.

Hełdak M., Raszka B. 2013. Evaluation of the Local Spatial Policy in Poland with Regard to Sustainable Development. Pol. J. Environ. Stud., 22 (2), 395-402.

Jeżak J., Wierzchowski M.W. 2014. The Effect of the Decision on Development Conditions on the Spatial Order of Polish Cities. Świat Nieruchomości, 89, 25-30.

Kopiński A., Porębski D. 2014. The use of Hellwig's method in the construction of an econometric model for the rate of return from investment funds. Annales Universitatis Mariae Curie-Skłodowska, sectio H-Oeconomia, 48 (3), 147-156.

Król K. 2015. Presentation of objects and spatial phenomena on the Internet map by means of net resource address parameterization technique. Geomat., Landmanag. Landsc. (GLL), 4, $35-47$.

Król K. 2016. Renta planistyczna i opłata adiacencka - wybrane zagadnienia prawne. Acta Sci. Pol., Formatio Circumiectus, 15 (4), 243-252.

Król K. 2018. Comparative analysis of the performance of selected raster map viewers. Geomat., Landmanag. Landsc. (GLL), 2, 23-32.

Król K., Prus B. 2016. The comparative analysis of selected interactive data presentation techniques on the example of the land use structure in the municipality of Tomice. Polish Cartographical Review, 48 (3), 115-127.

Król K., Prus B. 2017. Monitoring the use of the internet application for Tomice municipality local plan of spatial development. Geomat., Landmanag. Landsc. (GLL), 2, 91-98.

Król K., Prus B. 2018. Application of interactive charts in the evaluation of socio-economic development of regions. The case of Poland. Acta Sci. Pol., Formatio Circumiectus, 17(3), 141-151.

Król K., Szomorova L. 2015. The possibilities of using chosen jQuery JavaScript components in creating interactive maps. Geomat., Landmanag. Landsc. (GLL), 2, 45-54.

Nowak M. 2012. Decisions on building conditions and land management - a useful instrument or a development barrier?. Regional and Local Studies, 2 (48), 77-91.

Prus B., Król K. 2017. Evaluation of using selected taxonomic methods to classify socio-economic phenomena. Acta Sci. Pol., Formatio Circumiectus, 16 (2), 179-197.

Prus B., Król K., Chrobot K. 2018. Analysis of the correlation between socio-economic development and land prices. A study of the Zagnańsk municipality. Acta Sci. Pol., Formatio Circumiectus, 17 (2), 87-94. DOI: 10.15576/ASP.FC/2018.17.2.87 
Prus B., Szylar M. 2018. The analysis of settlement network's dispersion using Ward's taxonomy method. Survey Review. DOI: 10.1080/00396265.2017.1418279

Rokicka K. 2014. Decyzja o warunkach zabudowy - analiza prawno-porównawcza. Administracja, Teoria, Dydaktyka, Praktyka, 2 (35), 94-111.

Skrenty Ż. 2010. Podstawowe zasady planowania przestrzennego - istota i cele ustanowienia. PWSZ IPiA Studia Lubuskie, VII, 245-260.

Strategy for the Przecław Municipality 2016 [Strategia Gminy Przecław 2016]. Strategia Rozwoju Gminy Przecław na lata 2016-2026 [Development Strategy of the Przecław Municipality for the years 2016-2026]. https://goo.gl/8DHGan (accessed: 31.10.2018).

Ustawa z dnia 27 marca 2003 r. o planowaniu i zagospodarowaniu przestrzennym (Dz. U. z 2018 r., poz. 1945).

Ziemiańczyk U. 2010. An assessment of socio-economic development of rural and urban-rural communities in the Małopolska province. Infrastructure and Ecology of Rural Areas, 14, $31-40$.

Ziobrowski Z. 2009. Polityka przestrzenna a decyzje o warunkach zabudowy. Problemy Rozwoju Miast, 6 (4), 21-25.

Dr inż. Karol Król

Uniwersytet Rolniczy w Krakowie

Katedra Gospodarki Przestrzennej i Architektury Krajobrazu

30-059 Kraków, al. Mickiewicza 24/28

e-mail:k.krol@onet.com.pl

website: http://homeproject.pl

ORICD: https://orcid.org/0000-0003-0534-8471

Mgr inż. Jarosław Markulis

Uniwersytet Rolniczy w Krakowie

Katedra Gospodarki Przestrzennej i Architektury Krajobrazu

30-059 Kraków, al. Mickiewicza 24/28 